International Research Journal of Management, IT \& Social Sciences
Available online at https://sloap.org/journals/index.php/irjmis/
Vol. 6 No. 2, March 2019, pages: $1 \sim 11$
ISSN: 2395-7492
https://doi.org/10.21744/irjmis.v6n2.600

\title{
Values of Aesthetic and Religiosity towards Tourism Attraction
}

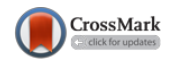

\author{
I Made Regeg a \\ Ida Bagus Gde Yudha Triguna ${ }^{b}$ \\ I Wayan Winaja ${ }^{\mathrm{c}}$
}

Article history:

Received: 18 September 2018

Accepted: 31 January 2019

Published: 14 February 2019

\section{Keywords:}

aesthetics;

religiosity;

tourism attractions;

tourist;

value;

\begin{abstract}
The theories used to analyze the problems included aesthetic theory, religious theory, and structural-functional theory. The three theories dissect the three problems found in this study. This research was methodically designed using a study approach to religion, culture, and qualitative methods. The implementation was carried out at the attraction of Soekasada Park in Ujung Karangasem. The type of data used was qualitative data obtained from primary and secondary sources. Field data were obtained from resource persons selected purposively. The researcher acted as the main instrument, assisted by interview guides, photo-cameras, and stationery. Field data was collected through observation techniques, in-depth interviews, and documentation. Data were analyzed by descriptive, qualitative, and interpretative techniques. The results of this study were values of aesthetic and religiosity at the location have implications for tourist visits, economy, arts, culture, education, and the dynamics of the people in Karangasem Regency, namely (1) Implications for tourist visits: increased visits during the last two years have increased 5.8\%, (2) Implications for the economy: there have been an increase in community economics, (3) Implications for art culture: there has been an increase in cultural arts creativity, 4) Implications for education: there was educational creativity increasing religious spiritual strength, self-control, personality, intelligence, noble character, and skills needed for himself, society, nation and country (5) Implications for the dynamics of the ummah, namely: (1) the increase of the people to pray and the harmony between humans and the God and their manifestations, humans and humans, and their environment.
\end{abstract}

2395-7492@ Copyright 2019. The Author. This is an open-access article under the CC BY-SA license (https://creativecommons.org/licenses/by-sa/4.0/) All rights reserved.

\footnotetext{
Author correspondence:

I Made Regeg,

Universitas Hindu Indonesia

Denpasar, Bali, Indonesia

Email address: regegbangkit.made@gmail.com
}

${ }^{a}$ Universitas Hindu Indonesia, Denpasar, Indonesia

${ }^{\mathrm{b}}$ Universitas Hindu Indonesia, Denpasar, Indonesia

${ }^{\mathrm{c}}$ Universitas Hindu Indonesia, Denpasar, Indonesia 


\section{Introduction}

In the era of globalism, the needs of human life are very complex, this means that people are increasingly creative. Many people have difficulty in fulfilling their needs. Humans are very preoccupied with work to meet their needs. Therefore, they forget to take care of themselves and forget about their health, both physical and non-physical. As a result of the busyness, humans are faced with suffering. That is the impact of globalization that is sweeping the world. The attitude of secularism is more concerned with worldly life and ignores religious values. The emergence of an attitude of luxury and extravagant lifestyle because a person's status in society is measured by their wealth.

The negative impact of globalization causes suffering for humans if there is no solution. In accordance with Google's search results, the solutions offered on the humans are not affected by the negative influence of globalisation namely by eating regularly, exercise, rest, recreation, and prayer, and often attend spiritual events. The regular of eating, breaks, exercise, and recreation are physical needs. It seems prayer/following religious activities is a spiritual need. These activities should be carried out in a balanced and harmonious manner. The recreational activities are closely related to places that have aesthetic values and religiosity. There are also some who are recreation to cultural attractions. Cultural tourism is very closely related to values of aesthetic and religiosity.

According to Eddy (2013), stated that cultural tourism and nature tourism will be more alive if it is inspired by aesthetic values and religiosity. Therefore, these values must not be lost. They must be maintained and preserved. Tilaar (2012), stated that those who lose their culture will lose their identity and will then be swept away in a soulless global change. Its cultural loss includes losing its aesthetic values. Cultural values will be seen from aesthetic values inspired by the values of the religiosity.

The aesthetic values that cause awe (kalangen), stunned, amazed and contain the meaning of goodness, truth, and pleasantness between observers and observed objects. In modern aesthetics more is discussed about art and aesthetic experience which are real symptoms and can be explored in an empirical and systemic way. Beauty as an aesthetic value (Triguna, 2003: 47). Art and aesthetics are the main capital of a park. The park functions as a place for recreation.

Recreation is a refreshing body and mind. Something exciting and refreshing like entertainment and picnic. Nowadays, domestic and international tourists visit tourism attractions for recreation. Some also have sports, prewedding photos, and see photos of the king. The word recreation is injected with fun, poetry and as a place of courtship for young people in the millennial era. The public's understanding of the tourist attraction is only known as a place of recreation because of its beauty. Thus, what is known only as a pool environment, even though the attraction consists of Tri Mandala. In addition, it is also not understood why, how and what are the implications of aesthetic values and religiosity. It is also understood as only a small part. Most people only know about parks only in the services area in the pool environment. Even though, there are still other areas that should be known by the public generally.

It is important to do an in-depth study of values of aesthetic and religiosity in the tourist attraction. The study was to find out the reasons, developments and implications of values of aesthetic and religiosity on the tourism attraction of Park Soekasada in Ujung Karangasem.

Regarding the above background, what are the implications of the development of values of aesthetic and religiosity towards tourism attractions on tourist visits, economics, cultural arts, education, and the dynamics of the people in Karangasem Regency? Therefore, the objectives to be achieved in the present study is to understand the implications of the development of values of aesthetic and religiosity on Soekasada Park, Ujung Karangasem.

\section{Literature review}

It becomes important due to the literature search gets inspiration, can be sharpened concepts and theories, add insight about things related to the research being carried out. In addition, library exploration is also intended to show substantial differences in this research from previous studies. Therefore, it can show originality and show differences and similarities between previous studies with this study. Thus, the research is feasible. There are several literature studies that have been conducted.

Soeksasada Park in Karangasem is a historical heritage of the Karangasem Kingdom consists of buildings that blend local cultural values (Bali), Dutch architecture and China. Its decryption, it was stated that in the north of the tourist attraction there was a temple called Pura Manikan (Manikan Temple) which was built by King Karangasem was used as a place of rest for the people and the Government of Karangasem Regency. In the present study, it was deeply discussed about values of aesthetic and religiosity in the tourism attraction of Soeksasada Park at Ujung Karangasem. 
Raharja (2012), examined the recontextualization of local excellence in the parks of the Bali Kingdoms in the Globalization era. It is based on the relics of royal gardens in Bali. It can be seen that traditional Balinese gardens have local advantages that come from tradition and indigenous (unique Balinese). Indigenous sources of royal heritage gardens in Bali have local philosophy, local knowledge, local technology, local skills, local material, aesthetics, and local idioms. The concept of the park and technology from outside culture has been received through a process of adaptation and combined (hybrid) with the concept of Balinese traditional gardens. Therefore, unlike enrich the design of the park in Bali, without destroying its essential values. Mandhara Giri's screening philosophy in Ksirarnawa and the Lingga-Yoni concept is a philosophy that originates from Indian-Hindu culture. Natural and artificial elements are interpreted from the elements in the mythology of the Mandhara Giri Screening in Ksirarnawa and the Lingga-Yoni concept are then adapted into the park design. Thus, creating an equilibrium between the demands of nature and humans. This element can give a distinctive character to traditional Balinese park designs.

The local superiority of the design of Balinese Traditional Park can be developed in the design of modern gardens amid global competition without destroying its essential values. Recontextualization of Balinese Traditional Park designs can be conducted through several strategies, to create designs with local superiority (local genius) based on indigenous sources (local peculiarities) can enrich the design of parks in Bali. The concept and philosophy of Balinese traditional garden design have universal values. It can create a positive contribution to civilization. Unlike ecological value, which respects the source of springs and protection (conservation) against natural springs. Tri Hitakarana philosophy is inspired by Tat Twamasi teachings and ecological values in Balinese traditional park concepts has similarities with western scientific theories that emerged in the $20^{\text {th }}$ century such as Gaia Theory, Ecological Awareness, and Planet Awareness. Raharja (2012), research is very relevant to support this research, especially on cultural and religious values. This study has inspired the practice of values of aesthetic and religiosity has been conducted a long time ago.

Eddy (2013), stated that (1) Reviving the glory of the Karangasem Kingdom and the relationship between the existence of Ujung Park and other historical relics such as Tirta Gangga, parks in place others related to history. (2) Preservation of cultural heritage related to tourism, especially cultural tourism. It is necessary to save Ujung Park, thus it can become a magnificent tourist attraction park in accordance with the initial conditions. (3) Preservation can take advantage of the existing potential and conceptualize the use of earthquake resistant building materials and is not easily corroded. The preservation of the cultural heritage related to cultural tourism in tourism attractions of Soeksasada Park in Ujung Karangasem. The research was also to preserve the cultural values found in there. The difference, in this study, examined in depth about values of aesthetic and religiosity at Soekasada Park in Ujung Karangasem. Therefore the study is quite relevant to be used as a source of supporting research studies and in determining the origin of this study. In this article studied in depth about values of aesthetic and religiosity.

Damayanti (2014), stated the tourism destination of Soekasada Park was built by Kingdom Karangasem Anak Agung Agung Anglurah Ketut Karangasem located in Tumbu Village. There are four factors underlying the development namely historical factors, cultural factors, and political factors. The study was very concise due to it only involved historical factors, cultural factors, and political factors. The research equation with this study both examined the tourism attraction of Soekasada Park in Ujung Karangasem. The difference is the result of the research on four factors underlying the development of Soeksasada Park in Ujung Karangasem. This study is to examine the values of aesthetic and religiosity. Thus, the research is quite relevant to become one of the sources of supporting research studies and in determining the origin of this study. This article discusses in depth about values of aesthetic and religiosity in the tourism attraction of Soeksasada Park in Ujung Karangasem.

Some studies and books although discuss tourism issues relating to this topic none of these studies discussed specifically and explained in detail about values of aesthetic and religiosity. The results of the research conducted above can be used as a reference in this present article, namely to convince researchers that cultural and spiritual tourism, especially values of aesthetic and religiosity have not been understood, why it is not known why, how and what the values are. Towards the social and economic life in Karangasem especially in Soeksada Park in Ujung Karangasem.

The research is helpful in addition to being very relevant in providing understanding and comparison of the problems in this study. However, from all the studies and results of these studies, there have not been or have not been studies/results of research that use a cultural study approach or paradigm. Therefore, this study is a new and original study and has significant differences with several previous studies. The difference is not only in terms of ontology (the center of attention, subject or object of study) and epistemological aspects (concepts, theories, approaches, models and methods) but also in terms of action (the purpose and benefits of this research).

Regeg, I. M., Triguna, I. B. G. Y., \& Winaja, I. W. (2019). Values of aesthetic and religiosity towards tourism attraction. International Research Journal of Management, IT and Social Sciences, 6(2), 1-11. 


\section{Materials and Methods}

Data collection techniques are techniques or ways that can be used by researchers to collect data. In this study, data collection in the form of information provided by informants greatly determines the success of the study. Therefore, carefulness in determining informants is one of the important keys in qualitative research. A good key informant is the participants who can be invited to share easily, who understands information is needed by researchers and likes to be invited to work together (Endraswara, 2006: 121). As a key informant, with considerations that refer to the view of Spradley (2007: 61), namely (1) full culture, meaning informants know and understand their culture well, (2) direct involvement, meaning informants are involved in a cultural atmosphere, using their knowledge to guiding their actions, reviewing things they know, (3) unknown cultural atmosphere. In this case, what is meant is that the researcher determines the informant who is not from the same area as the researcher, (4) sufficient time, the informant must be chosen who is not too busy, (5) non-analytical meaning the informant who does not carry out analysis regarding the meaning or significance of the event and action. It is good also chooses informants who can provide understanding analysis of various events from the perspective of "indigenous theory" (Spradley, 2007: 59-70; Endraswara, 2006: 206-207).

\section{Observation Technique}

Nazir (2008: 212), stated observation used of the direct observation as a way of collecting data has several advantages included (1) there is a possibility to record things, behavior, growth etc. The incident occurs, therefore, it does not hang data from someone's memory, (2) it can obtain data from the subject, both those who cannot communicate verbally and who do not want to communicate verbally. Observations in the present study were carried out by looking directly at the tourism attraction of Soekasada Park in Ujung Karangasem.

\section{Interview Technique}

Interviewing is a form of communication between two people, involving someone who wants to get information from another person by asking questions, based on certain goals. In this study using in-depth interviews to find out opinions, perceptions, feelings, knowledge, experiences, and sensations of a person (Mulyana, 2001: 180; Moleong, 2010: 190). The stages of the interview include (a) determining who was interviewed, (b) preparing for the interview, (c) the initial movement, (d) conducting an interview and maintaining a productive interview, and (e) stopping the interview and obtaining a summary of the interview results.

\section{Library Research}

Library study is the collection of data from written sources, such as books and scientific magazines including the results of previous studies that are relevant to the research theme. In fact, according to Zed (2004: 1), almost all types of research require literature. Nawawi (1995: 141), explained that in each study cannot be separated from scientific literature, thus, library research activities become very important.

\section{Data Analysis Technique}

Data analysis, in essence, is conducted continuously from the beginning to the end of the study. In analyzing the data, various actions are used in the form of intensive data extraction, also related categorization and compilation of all of which are based on the acquisition of data from the scene (Moleong, 2010: 44). In addition, interpretation is given, namely giving meaning, explaining patterns or categories, and also look for characteristics of various concepts. In this article, data analysis was performed using three interrelated stages included data reduction, data presentation, and drawing conclusions (verification) (Milles \& Habermen, 1992: 364). The four stages are as follows.

Data classification is the stage of grouping data obtained based on data collection techniques while digging data in the field. According to Bogdan \& Biklen (2005), at the end of the analysis during data collection, the determination of the objectives of data collection was conducted. Data collected from both the informant, the situation and the documents specified. Classification in this research is conducted through grouping data consisting included (1) data obtained from observation, (2) data obtained from interviews, and (3) data obtained from the results of documentation studies. This treatment is very important to facilitate checking and subsequent analysis. 
Data reduction according to Milles \& Huberman (1992), is an electoral process, the formulation of attention to simplification, abstracting, the transformation of the primary data, which arises from field notes. Data reduction continues throughout the study. Before the data is actually collected, the anticipation of the reduction has occurred without the researcher at the time of the study deciding the research area conceptual framework, research problems, and the chosen data collection approach.

Data interpretation is conducted during the research process. It starts from data collection which aims to obtain special meaning related to the symbolic activity. This refers to Geertz (1992: 89), who adheres to the view that culture as a system of the conception is inherited and implemented in symbolic form. Thus, the qualitative interpretation of this research is the interpretation of the uses, ideas, and concepts that exist in this theme.

The verification and drawing conclusions are the final steps of processing the data. Verification is checking the correctness of the analysis in the form of interpretation and meaning that has been done. Therefore, the conclusion is also correct. It is conducted in each group of data based on the problems studied. Next, draw a conclusion on each of the problems discussed.

In order to support the analysis process, the data obtained must be complete and comprehensive in the setting of the environment. In this case, the setting in question is the context in which the speech must occur clearly. Therefore, the context of each speech must be included completely as a basis for drawing conclusions. If the conclusions are felt to be less than solid on the basis of the first (previous) observation, the researcher returns to collect data to perfect the results based on more robust findings (Zuriah, 2006: 94).

Furthermore, due to the researcher involved as the main instrument or key instrument, there is a possibility that the subjectivity element of the researcher refracts this research data. In order to suppress, even negate the subjectivity, so that, the bias can be minimized, researchers need to check the validity of the data collected. Moleong (2004: 175), offered a number of techniques that can be used to examine or test the validity of the data included through (1) extension of participation, (2) perseverance of observation, (3) triangularization, (4) checking through colleagues, (5) availability of sufficient references, etc.

\section{Presentation Techniques of Data Analysis Results}

The presentation stage is the stage of the description of the research results in the form of sequential and integral writing. In this context, the presentation of the study results is conducted informally, i.e., the results presentation of the research conducted using descriptions of words with various scientific languages supported by formal presentation techniques. The presentation is made in such a way that it is able to describe the existence of real cultural phenomena of the social studied.

\section{Concepts of Value and Religiosity}

Djahiri (1985: 20), stated that value is a believes/belief that comes from a person's value system, about what someone should do or about what is valuable from what is not valuable. In accordance with these opinions Mulyana (2004: 23), stated that value as an abstract reality, the value felt in a person as a driver and the principle of life. Religiosity is a complex system consisting of beliefs. The beliefs reflected in attitudes and carrying out religious ceremonies in order to be able to relate to Hyang Widhi/God (Mangunwijaya, 1988: 2-6).

\section{Concepts of Aesthetics and Tourism Attraction}

The aesthetic value used in this study is a combination of pure aesthetic values, the aesthetic value concerns a person's aesthetic experience in relation to everything that is absorbed through vision, civilization, and feelings, all of which can lead to beautiful perceptions in the work or art object. In this case, the Dutch, Chinese, and Balinese architectural works, and natural beautiful works i.e., mountain and sea towards the tourism attraction of Soekasada Park in Ujung Karangasem. According to Law Number 10 in 2009 stated that tourism attraction is anything that has a unique, beautiful, and value in the form of natural, cultural, and human-made diversity that is the target or destination of tourist visits.

Regeg, I. M., Triguna, I. B. G. Y., \& Winaja, I. W. (2019). Values of aesthetic and religiosity towards tourism attraction. International Research Journal of Management, IT and Social Sciences, 6(2), 1-11. 


\section{Theory of Aesthetic}

Theory of aesthetic basically can be divided into three included (1) Theory of formal aesthetic related to classical art and classical thoughts. The beauty outside the building concerns the problem of shape and color. This theory assumes that beauty is a formal result of height, width, size (dimensions) and color. A sense of beauty is a direct emotion that is caused by form regardless of other concepts. This theory demands an absolute ideal concept that is addressed by beautiful forms, leads to mysticism. (2) Theory of expressionist aesthetic stated that beauty is not always incarnated from its form but from its intentions or expressions. This theory assumes that the beauty of artwork depends primarily on what it expresses. In architectural beauty produced the most perfect expression between the strength of attraction and the strength of the material. The main assumption of the beauty of architecture is the expression of the function or usefulness of a building. (3) Theory of psychological aesthetic.

The theory of aesthetic psychological of beauty has three aspects included (1) Beauty in architecture is a simple and easy rhythm. In architecture, observers feel that they are doing what the building does in a simple, easy, and flexible way. (2) Beauty is a result of emotions that can only be demonstrated by psychoanalytic procedures. The artwork gets the power of its beauty from a reaction that is entirely different. (3) Beauty is the result of the observer's own sense of satisfaction with the object shows. The three theories are manifestations to explain the beauty of various perspectives i.e., mystically, emotionally or scientifically scientific (Surajio, 2005: 123).

In the context of this study, the theory of aesthetic becomes relevant and significant to help eclectically solve problems that have been formulated. Therefore, it can be known in depth about the occurrence of aesthetic values and religiosity in the tourist attraction of Soeksasada Park in Ujung Karangasem.

\section{Theory of Religion}

Koentjaraningrat (2004: 144-145), stated that every religion is a system consisting of four components included (1) Religious emotions that cause humans to become a religion. Religious emotion is a vibration that moves the human soul. This process occurs when humans enter God's light. The vibration of the soul called religious emotion can be felt by an individual in their own circumstances. A religious activity can be carried out by a person in a state of silence. A person can pray, prostrate or perform solitary prayers in a state of being afflicted by religious emotions. Wherein, s/he will imagine God, Gods, spirits or others. The manifestation of what was imagined was determined by the beliefs that are commonly lived in society and culture, and/then its religious behaviors will also be carried out according to the custom that is commonly applied. (2) The belief system contains human beliefs and images about God's nature, about the forms of the supernatural, various supernatural things, and also about the nature of life and death. (3) the system of religious ceremonies, religious ceremonial systems which aim to find relationships between humans and God, gods or subtle creatures in the supernatural. This religious ceremonial system implements, symbolizes, various concepts contained in the belief system. The system of belief is a manifestation of the behavior or embodiment of religion. (4) Religious groups (adherent or social unity) or social entities that adhere to the belief system and who carry out the ceremonial system religious ceremonies, which consist of (a) core family or other small kinship groups (b) larger kinship groups such as extended families, unilineal families such as clans, tribes, dadia, etc. (c) community units such as villages, village combination, etc. (d) religious organizations such as religious broadcasting organizations, church organizations, political parties based on religious ideology, religious movements, secret orders and so on.

\section{Theory of Structural Functional}

According to Soyomukti (2010: 70), the view is deeply rooted in sociology, characterizing itself in the belief in the tradition of regularity (emphasizing the importance of ways to maintain social order). This flow gives attention to the establishment, social order, agreement, social integration, social solidarity, and satisfaction of needs and reality (empirical). This theory emphasizes order and ignores conflicts and changes in society. The society is a social system consisting of parts or elements that are interrelated and mutually integrated into balance. The changes that occur in one section will also bring changes to the other parts. The basic assumption is that every structure in the social system is functional towards the other. Conversely, if it is not functional, the structure will not exist or disappear by itself (Ritzer: 2004: 25). 


\section{Results and Discussions}

The implications of the values development of aesthetic and religiosity on the tourist attraction of Soeksasada Park in Ujung Karangasem. The development included tourist, economic, cultural, educational, harmony and religious visits in Karangasem Regency. The implication is (1) involvement or the situation involved; the human being as the object of the experiment or research the more the benefits and interests are felt; (2) which is included or knotted; which is suggested, but not stated: is there a question? (KKBI, 1999) Implications are the effects that are caused in the future and/or the impact felt when doing something or (understanding the information/understanding implications).

Based on the above description, the implications intended in this study are the effects that are felt when there is the values development of aesthetic and religiosity in the tourist attraction of Soekasada Park in Ujung Karangasem. The implementation of tourist visits, economics, arts and culture, education, the dynamics of the society. It was renovated tourist visits that were previously still low became increasing. The increase in tourist visits is inseparable from the values development of aesthetic and religiosity. The government through managers continues to fix values of aesthetic and religiosity.

\section{Implications toward Tourism Visits}

In 2016, the number of international tourism and domestics in the archipelago was 164,314 people with an average: 13,692.83. the visitation for foreign tourists in 2017 about 56,226 with an average visit was 4685.5, tourist visits of the archipelago totaled 122,051 with an average visit reaching 10170,92. In 2017, the number of international tourism and domestics in the archipelago was 178,277 with an average of about 14856.42. Tourism visits in the 2016 and 2017 for foreign tourist visits increased approximately 7,424 (15\%), domestic tourist visits increased approximately 6,539 (6\%), the increase in the last two years was $13,963(8.5 \%)$.

\section{Implications towards Economy}

The implications for the social economy in Ujung Tengah, Ujung Mantri, Ujung Pesisi and Ujung Hyang, as well as Seraya as a result of the development of the Soekasada Park regarding tourism attractions in Karangasem with the development of values of aesthetic can be seen from increasing economic structure, increasing income of some communities and creating new jobs.

Tourism is seen as a multidimensional activity from a series of development processes. Development of the tourism sector concerns social, economic and political aspects (Spillane, 1994: 14). This is in accordance with what is stated in Law No. 10 in 2009 concerning tourism about the implementation of tourism is intended to increase national income in order to improve the welfare and prosperity of the people, expand, and equalize business and employment opportunities, encourage regional development, introduce, and utilize tourist objects and attractions in Indonesia and foster a sense of love for the homeland and strengthen friendship between nations. The development of tourism also encourages and accelerates economic growth. The tourism activities create demand both consumption and investment which in turn will lead to the goods of production and services. During tours, tourists shop, so that, it directly raises market demand for goods and services. Furthermore, tourists indirectly cause the demand for capital goods and materials to produce to meet tourist demand for these goods and services. In an effort to meet tourist demand, investment in transportation and communication, hospitality and other accommodation are needed, the handicraft industry and the consumer product industry, service industries, restaurant and others (Spillane, 1994: 20). It is visible increases in tourist visits.

Respecting the increase in tourist visits in the tourist attraction of Soekasada Park Ujung Karangasem, there are creative activities in the economic sector to meet tourist demand. Unlike increasing activities in the fields of transportation and communication, hospitality and other accommodation, the handicraft industry and the consumer products industry, service industries, restaurants, and others. The increase in tourist visits, there is also etiquette income in the Ujung place neighborhood. Thus, it will be able to improve the economy of the community in Tumbu Village, especially, Ujung Tengah and its surroundings. This is in accordance with theory of structural-functional which suppresses the balance of social functions and structures, therefore, to increase the economy of the community.

Regeg, I. M., Triguna, I. B. G. Y., \& Winaja, I. W. (2019). Values of aesthetic and religiosity towards tourism attraction. International Research Journal of Management, IT and Social Sciences, 6(2), 1-11. 


\section{Implications towards Cultural Arts}

The values of the aesthetic in the tourist attraction of Soekasada Park Ujung Karangasem have implications for the arts and culture in Karangasem Regency. The implication is the development of values of potential cultural arts and reviving traditional arts groups in. This implication occurs due to the balance between the natural environment and its management. Therefore, nature still looks aesthetic and produces a noble aesthetic value is visited by many domestic and foreign tourists. There is also a balance between the government and owner (the private sector), thus, it is able to display the best for tourism attractions at Soekasada Park. regarding the regularity, it will bring together artists in Karangasem regency because they have the opportunity to perform there.

This is in accordance with the theory of structural-functional. According to Soyomukti (2010: 70), viewing is strongly rooted in sociology, characterizing itself in the belief in the tradition of order (emphasizing the importance of ways of maintaining social order). This flow gives attention to the establishment, social order, agreement, social integration, social solidarity, and satisfaction of needs and reality (empirical).

\section{Implications towards Education}

Education especially in increasing spiritual strength, self-control, personality, intelligence, noble character, and skills needed by themselves, society, nation, and state in accordance with Law No. 20 in 2003. It is also through the implementation of competitions and recreation in tourism attractions of Soekasada Park Ujung Karangasem will have implications for the formation of the subtlety of conscience. This is in accordance with the notion of education revealed by Gunning (1978). Definition of education according to Gunning and Kohnstamm is the process of forming a conscience. An ethical formation and self-determination that is in accordance with conscience.

\section{Implications towards Adherents Dynamics}

Implications for the dynamics of adherents (1) towards harmony in the tourist attraction of Soekasada Park Ujung Karangasem. The focus of harmony is the state of harmony. Harmony aims to achieve harmony in the life of society, nation, and state (KBBI, 1999: 390). Harmony in the broad sense is behavior that is in accordance with religious norms and state norms, unlike peaceful relations, peaceful relations, and soothing relationships. This harmony can occur in accordance with the theory of structural-functional, emphasizes order and ignores conflicts and changes in society. According to this theory, society is a social system consisting of parts or elements that are interrelated and mutually integrated into balance. The changes that occur in one section will also bring changes to the other parts. The basic assumption is that every structure in the social system is functional towards the other. Conversely, if it is not functional, the structure will not exist or disappear by itself (Ritzer: 2004: 25). Related to the harmony, it means that there is no commotion (conflict), there is no misunderstanding, no negative influence, provocative from managers, traders, the government, the royal family, and visitors to Soekasada Park Ujung Karangasem.

The activities of values of religiosity can also be seen from the managers and all managers and the community in Soekasada Park Ujung Karangasem of tourism attraction environment. It is seen enthusiastically every day at Padmasana and Pelinggih Dirah, which is well known throughout Bali and the archipelago. In fact, it can be seen that there is harmony in the management environment, the government, the heir of tourism attraction and visitors (tourists) and harmony with the natural environment around the park. (2) Implications for the development of pemedek (adherents) come to the tourism attraction of Soekasada Park Ujung Karangasem. This happened because of the belief of the people towards Pelinggih Dirah giving to salvation, from accusations of carrying out black magic e.g., ngeliak, nesti, neluh dan trenjana and begging for offspring. This is in accordance with the religious theory i.e., (a) religious emotions that cause humans to become religious, (b) belief systems that contain human beliefs and images of God's nature, about manifestations of the supernatural, various supernatural things, and also about the nature of life and death, (c) the religious ceremonial system aims to find relations between humans and God, the gods or subtle creatures that exist in the supernatural world. This religious ceremonial system implements, symbolizes, various concepts contained in the belief system. The system of belief is a manifestation of the behavior or embodiment of religion, (d) religious groups (adherents or social unity) (Koentjaraningrat, 2004: 144-145).

Soekasada Park Ujung Karangasem initially was the people only offered the Ujung people and Ujung neighborhood prayers, and the tourist attraction of Soekasada Park. Regarding the development of Soekasada Ujung Karangasem religiosity, prayers from Ujung Karangasem and outside the regency are growing and experiencing tremendous improvement. Pelinggih Dirah is a place wherein the manners beg for salvation, secrecy and even for krama (society) 
who are accused of being able to do black magic (neluh, tranjana, ngeliak and nesti) come to melukat (cleaning body spiritually) and beg to be cleansed physically and physically from the society.

Based on the interviews above, it can be emphasized that the implications of values of religiosity on the Soekasada Park tourism attractions in Ujung Karangasem can increase courtesy visits in Karangasem Regency and many regencies/cities in Bali are present to offer prayers.

\section{Conclusion}

Based on the above analysis, the results of this study can be drawn. The values of aesthetic and religiosity at the research location have implications for tourist visits, economy, art culture, education, and the dynamics of the people in Karangasem district included (1) Implications for tourist visits, there has been an increase in visits over the past two years, 58\%. (2) Implications for the economy, an increase in the economy of the community. (3) Implications for cultural arts, an increase in cultural arts creativity. (4) Implications for education, there is educational creativity increasing religious spiritual strength, self-control, personality, intelligence, noble character and the skills needed for him, the community, the nation, and the country. (5) Implications for the dynamics of the adherents i.e., (a) the increase of the people to pray and (b) the harmony between humans and Hyang Widhi and their manifestations, humans, and humans as well as their environment.

\section{Conflict of interest statement and funding sources}

The authors declared that they have no competing interest. The study was financed by personal funding.

\section{Statement of authorship}

The authors have a responsibility for the conception and design of the study. The authors have approved the final article.

\section{Acknowledgments}

The author would like to thank the editor of IRJMIS for their support, advice and valuable time in completing the present article.

Regeg, I. M., Triguna, I. B. G. Y., \& Winaja, I. W. (2019). Values of aesthetic and religiosity towards tourism attraction. International Research Journal of Management, IT and Social Sciences, 6(2), 1-11. 


\section{References}

Aquinas, T., \& Mangunwijaya, Y. B. (1988). Wastu Citra: Pengantar Ilmu Budaya Bentuk Arsitektur Sendi-sendi Filsafatnya. Jakarta: PT Gramedia.

Bogdan, R., \& Biklen, S. K. (1997). Qualitative research for education. Boston, MA: Allyn \& Bacon. https://s3.amazonaws.com/academia.edu.documents/31190365/

Damayanti, W. D., Mudana, I. W., \& Margi, I. K. (2014). Identifikasi Potensi Taman Soekasada Ujung, di Desa Tumbu, Kabupaten Karangasem, Bali sebagai Sumber Belajar Sejarah Lokal di SMA. Widya Winayata: Jurnal Pendidikan Sejarah, 2(1). https://ejournal.undiksha.ac.id/index.php/JJPS/article/view/4277

Eddy, I. W. T. Konservasi Pusaka Budaya Istana Taman Ujung Karangasem. Journal of Bali Studies, 3(2). https://ojs.unud.ac.id/index.php/kajianbali/article/view/15690

Endraswara, S. (2003). Mistik kejawen: Sinkretisme, simbolisme, dan sufisme dalam budaya spiritual Jawa. Penerbit Narasi. https://books.google.co.id/books?hl=en\&lr=\&id=eDYCt_L6hrgC\&oi

Gede, I., Raharja, M., Made, I., Pande Artadi, S. S., Ayu, I., Dyah Maharani, S. T., \& Ds, M. (2012). Rekontekstualisasi Keunggulan Lokal Taman Peninggalan Kerajaan-kerajaan di Bali Pada Era Globalisasi. http://repo.isidps.ac.id/1609/

Greetz, C. (2000). Interpretace kultur. Vybrané eseje.

Gunning, D. (1978). The teaching of history. Taylor \& Francis.

Koentjaraningrat, Prof. "dr. 2004." Manusia dan Kebudayaan di Indonesia.

Miles, M. B., \& Huberman, A. M. (1992). Analisis data kualitatif.

Moleong, L. J, 2002 Metode Penelitian Kualitatif. Bandung: PT. Remaja Rosdakarya.

Moleong, L. J. (1999). Metodologi penelitian. Bandung: PT. Remaja Rosda Karya. http://www.academia.edu/download/31056882/07130097-hendra-kurniawan.pdf

Mulyana, R. (2004). Mengaktualisasikan Pendidikan Nilai. Bandung: Alfabeta.

Nawawi, H. H., \& Hadari, H. M. (1992). Instrumen penelitian bidang sosial. Gadjah Mada University Press.

Nazir, M. S., \& Afza, T. (2009). Impact of aggressive working capital management policy on firms' profitability. IUP Journal of Applied Finance, 15(8), 19. https://www.researchgate.net/profile/Talat_Afza/publication/228320063

Ritzer, G., \& Goodman, D. J. (2004). Teori sosiologi modern. Jakarta: Prenada Media, 121. http://www.academia.edu/download/34703444/

Soyomukti, N. (2010). Pengantar Ilmu Komunikasi. Ar-ruzz media.

Spillane, J. J. (1994). Pariwisata Indonesia: siasat ekonomi dan rekayasa kebudayaan (Vol. 5). Kanisius.

Spradley, J. P. (2016). The ethnographic interview. Waveland Press. https://books.google.co.id/books?hl=en\&lr=\&id=KZ31CwAAQBAJ\&oi

Surajiyo, D. (2005). Ilmu Filsafat (Suatu Pengantar).

Tilaar, H. A. (2012). R, dan Riant Nugroho. Kebijakan Pendidikan: Pengantar untuk Memahami Kebijakan Pendidikan dan Kebijakan Pendidikan sebagai Kebijakan Publik. Yogyakarta: Pustaka Pelajar.

Tim Penyusun, K. B. B. I. (2008). Kamus Besar Bahasa Indonesia. Balai Pustaka: Jakarta.

Triguna, I. B. G. Y. (1997). Mobilitas Kelas, Konflik dan Penafsiran Kembali Simbolisme Masyarakat Hindu di Bali. Unpad Bandung.

Zed, M. (2004). Metode peneletian kepustakaan. Yayasan Obor Indonesia. https://books.google.co.id/books?hl=en\&lr=\&id=iIV8zwHnGo0C\&oi

Zuriah, N. (2006). Metodologi penelitian sosial dan pendidikan: teori, aplikasi. Bumi Aksara. 


\section{Biography of Authors}

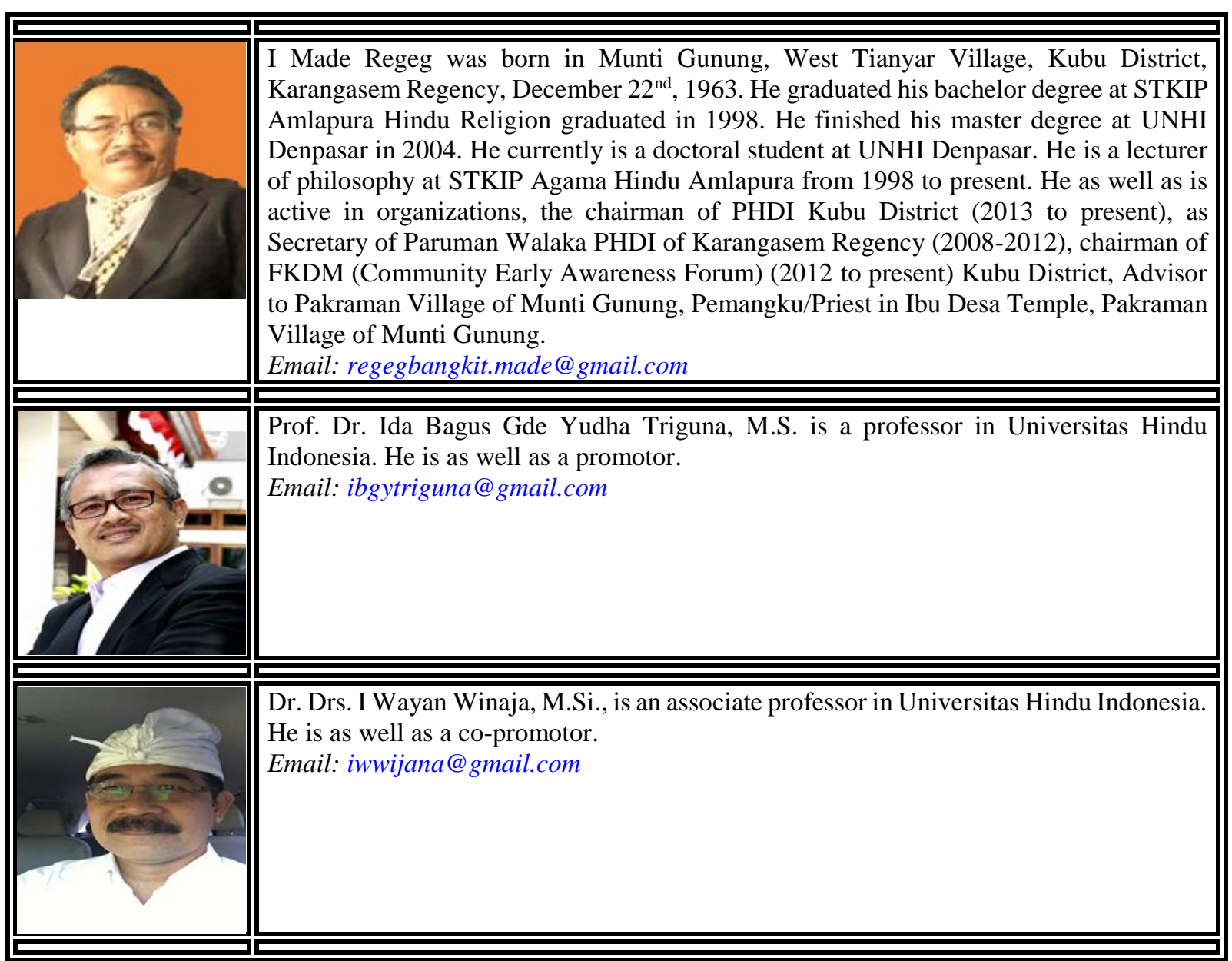

Regeg, I. M., Triguna, I. B. G. Y., \& Winaja, I. W. (2019). Values of aesthetic and religiosity towards tourism attraction. International Research Journal of Management, IT and Social Sciences, 6(2), 1-11. 